\title{
CINIA
}

The $2^{\text {nd }}$ Conference on Innovation and Industrial Applications (CINIA 2016)

\section{Pemetaan Kerentanan Tsunami Kabupaten Lumajang Menggunakan Sistem Informasi Geografis}

\author{
Amien Widodo ${ }^{1}$, Dwa Desa Warnana ${ }^{2}$, Juan Pandu G N R ${ }^{3}$, Wien Lestari ${ }^{4} \&$ Ary Iswahyudi $^{5}$ \\ 1,2,3,4 Dosen, FTSP, Teknik Geofisika, ITS \\ ${ }^{5}$ Dosen, Universitas Islam Madura \\ *wienlestari02@gmail.com
}

\begin{abstract}
Abstrak
Kabupaten Lumajang merupakan wilayah yang rentan terhadap tsunami karena berbatasan langsung dengan Pantai Selatan yang menjadi pusat gempa bumi serta keadaan pesisir pantai selatan Lumajang yang memiliki tingkat kepadatan penduduk dan pemukiman, aktivitas pemerintahan dan perekonomian yang tinggi. Pemetaan tingkat kerentanan tsunami perlu dilakukan sebagai informasi mitigasi dan rencana tata ruang wilayah. Lokasi penelitian adalah 5 (lima) kecamatan di pesisir Pantai Selatan Lumajang yaitu Yosowilangun, Kunir, Tempeh, Pasirian, dan Tempursari. Tujuan penelitian ini adalah membuat peta kerentanan tsunami Kabupaten Lumajang menggunakan Sistem Informasi Geografis (SIG). Pendekatan variabel kerentanan meliputi elevasi daratan, kemiringan, morfometri pantai, penggunaan lahan, jarak dari pantai dan jarak dari sungai. Metodologi penelitian antara lain pengumpulan data primer dan sekunder, pengolahan data parameter yang mewakili tiap variabel kerentanan serta pemberian bobot dan skor. Hasil kajian ini menghasilkan peta-peta variabel kerentanan wilayah penelitian yang selanjutnya dapat digunakan untuk kebijakan pemerintah daerah dan tindakan mitigasi seperti pemetaan tingkat risiko tsunami.
\end{abstract}

Kata kunci: Peta Kerentanan Tsunami, Sistem Informasi Geografis, Kabupaten Lumajang.

\section{PENDAhUluan}

\subsection{Latar Belakang}

Kabupaten Lumajang dekat dengan pertemuan dua lempeng yaitu Eurasia dan Australia yang berjarak hanya sekitar $250 \mathrm{~km}$ dari pesisir pantai. Faktor inilah yang menjadi alasan akhirnya Kabupaten Lumajang masuk dalam kategori risiko bencana gempa bumi dan tsunami terberat di Provinsi Jawa Timur bersama dua daerah lainnya, yakni Kabupaten Pacitan dan Kabupaten Tulungagung. Pantai Lumajang mempunyai hamparan sepanjang 76 km dari wilayah Kecamatan Tempursari hingga Yosowilangun. Karakter pantai di Lumajang adalah mempunyai ombak besar berlapis-lapis yang tingginya bisa mencapai 3 meter. Kerentanan menurut UNSDR (2004) adalah suatu kondisi dari masyarakat atau komunitas yang ditentukan oleh faktor fisik, sosial, ekonomi dan lingkungan yang meningkatkan ketidakmampuan dalam menghadapi suatu bencana . tsunami merupakan suatu ancaman yang dapat menimbulkan kerugian dan korban yang sangat besar. oleh karena itu penting sekali diupayakan mitigasi bencana tsunami yaitu proses mengupayakan berbagai tindakan preventif untuk meminimalkan dampak negatif bencana tsunami yang diperkirakan akan terjadi. salah satu langkah mitigasi tersebut adalah membuat peta kerentanan tsunami.

\subsection{Tujuan Penelitian}

Tujuan kajian pemetaan kerentanan tsunami Kabupaten Lumajang ini adalah

1. Mengidentifikasi faktor-faktor dan indikator kerentanan tsunami yang meliputi kerentanan fisik, ekonomi, sosial dan lingkungan.

2. Membuat pemetaan kerentanan bencana tsunami menggunakan Sistem Informasi Geografis (SIG).

\subsection{Lokasi Kegiatan}

Kegiatan ini meliputi 5 Kecamatan di Kabupaten Lumajang yang berbatasan langsung dengan Pantai Selatan yaitu Kecamatan Yosowilangun, Kecamatan Kunir, Kecamatan Tempeh, Kecamatan Pasirian, Kecamatan Tempursari.

\section{TINJAUAN PUSTAKA}




\subsection{Kajian Geologi Regional Kabupaten Lumajang}

Kabupaten Lumajang disusun secara geologi oleh batuan-batuan dari Formasi Mandalika (Formasi Wuni, Tuf Argopuro), Batuan Gunung api Jembangan (Tengger, Semeru, dan Lamongan), Endapan Rawa, dan Aluvium. Secara stratigrafi Formasi Mandalika merupakan satuan tertua di wilayah ini yang diperkirakan berumur Oligosen Akhir-Miosen Awal menempati sebagian kecil wilayah kabupaten Lumajang bagian barat daya. Wilayah ini juga terdiri atas batuan piroklastik dan lava bersusunan andesitik $\hat{A}-$ basaltik yang umumnya telah terpropilitkan. Tidak selaras diatas batuan gunung api tua ini diendapkan Formasi Wuni berumur Miosen Tengah yang bercirikan perselingan breksi, lava, breksi tufa, breksi lahar, dan tufa pasiran yang tersebar di sebagian kecil daerah bagian barat daya. Kedua formasi diatas ditutupi oleh satuan-satuan stratigrafi berumur Plistosen yang disusun oleh Tuf Argopuro di bagian timur, hasil kegiatan gunung api Jembangan, Tengger, dan Semeru di bagian utara dan tengah, serta hasil kegiatan gunung api Lamongan di bagian timur laut. Endapan rawa diendapkan di bagian selatan wilayah Kecamatan Pronojiwo sementara aluvium menempati bagian pedataran di sebelah timur Lumajang.

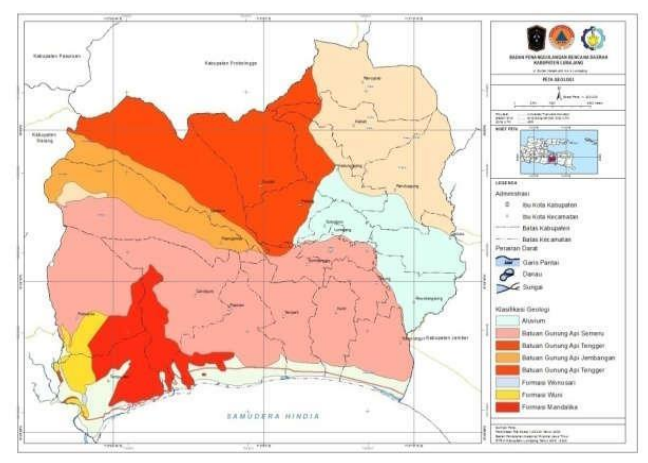

\section{Gambar 1. Peta Geologi Regional Kabupaten Lumajang}

\subsection{Kondisi Topografi Kabupaten Lumajang}

Wilayah Kabupaten Lumajang memiliki garis pantai yang berhadapan langsung dengan Samudera Hindia, yang secara geologis merupakan daerah tepian benua aktif yang dicirikan dengan aktivitas kegempaan yang intensif dan sebagian berpotensi menimbulkan tsunami. Wilayah pantai daerah penelitian umumnya berbentuk teluk, baik terbuka maupun semi tertutup. Pantai berteluk tersebut memiliki dataran pesisir dengan morfologi yang relatif datar dan dimanfaatkan penduduk sebagai pemukiman dengan segala aktivitasnya. Menurut Penelitian dari Balai Arkeologi Yogyakarta tahun 1995 keadaan alam Lumajang secara fisik dapat dibagi menjadi 3 bagian :

1. Bagian Utara. perbukitan dan pegunungan dengan lingkungan alam yang kering dan tandus.

2. Bagian Tengah. Dataran rendah sampai dataran tinggi (perbukitan dan pegunungan) dengan lingkungan alam yang basah dan sebagian besar merupakan Daerah Aliran Sungai Bondoyudo dan Daerah Aliran Sungai Asem

3. Bagian Selatan. Dataran rendah dan dataran tinggi dengan lingkungan alam yang basah dan kering dan sebagian merupakan tanah pasir yang kurang subur. Daerah ini merupakan bagian Daerah Aliran Sungai Mujur, Rejali, Glidik dan Pancing. Sungai-sungai besar dengan daerah aliran di lumajang dan sekitarnya antara lain Sungai Besuk Sat, Sungai Bondoyudo, Sungai Kaliasem, Sungai Kalimujur, Sungai Kalipancing, dan Sungai Rejali yang hampir kesemuanya bermuara di Pantai Laut Selatan.

Laporan Badan Penanggulangan Bencana Daerah (BPBD) Kabupaten Lumajang menyatakan bahwa ada 15 Desa di 5 wilayah Kecamatan yang termasuk zona bahaya bencana tsunami dengan total penduduk yang rawan terdampak di 15 desa tersebut mencapai 339.537 jiwa. Kelima wilayah tersebut berada di sepanjang garis pantai $75 \mathrm{~km}$ yang diperlihatkan pada gambar 3.4, diantaranya 4 desa pesisir di Kecamatan Pasirian, 2 desa pesisir di Kecamatan Tempeh, 3 desa pesisir di Kecamatan Yosowilangun, 1desa pesisir di Kecamatan Kunir, dan 5 desa pesisir di Kecamatan Tempursari. BPBD telah membentuk DESTANA (Desa Tanggap Bencana) untuk mengantisipasi terjadinya tsunami yaitu Desa Wotgalih (Kecamatan Yosowilangun), Desa Jatimulyo (Kecamatan Kunir), dan Desa Tegalrejo (Kecamatan Tempursari). Dua dari lima kecamatan yang memiliki tempat lebih aman untuk lokasi pengungsian dan jalur evakuasi yaitu Kecamatan Pasirian dan Kecamatan Tempursari. BPBD telah memasang Early Warning System (EWS) sederhana di dua desa yaitu Desa Bades (Kecamatan Pasirian) dan Desa Tempursari (Kecamatan Tempursari). Pusat Pengendali Operasi di Kantor BPBD Lumajang yang menerima informasi gempa dari BMKG akan meneruskan informasi ke kecamatan untuk diteruskan ke pos pantau. 


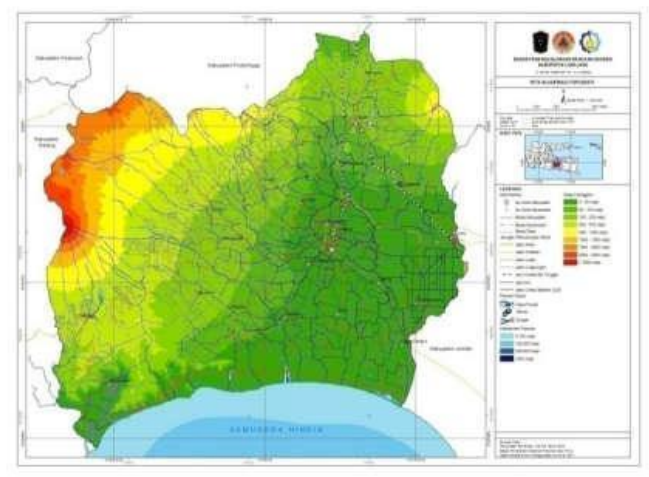

Gambar 2. Peta Topografi Kabupaten Lumajang

\subsection{Kerentanan (Vulnerability)}

Kerentanan atau vulnerability adalah suatu kondisi yang ditentukan oleh faktor-faktor atau proses-proses fisik, sosial, ekonomi, dan lingkungan yang menyebabkan peningkatan kerawanan masyarakat dalam menghadapi ancaman atau bahaya. Kerentanan meliputi beberapa aspek, antara lain:

- $\quad$ Fisik dan Lingkungan

Kepadatan bangunan, bahan bangunan, jenis dan kekuatan struktur bangunan

- Sosial Kependudukan

Jumlah dan kepadatan penduduk, stratifikasi penduduk (balita-lansia)

- Sosial Ekonomi

Jumlah penduduk miskin, pengangguran, keseagaman pekerjaan, dll.

\subsection{Tsunami}

Tsunami berasal dari Bahasa Jepang yang berarti gelombang ombak lautan ("tsu" berarti lautan, "nami" berarti gelombang ombak)berartitsunami adalah serangkaian gelombang ombak laut raksasa yang timbul karena adanya pergeseran di dasar laut akibat gempa bumi.

\subsection{Sistem Informasi Geografis (SIG)}

Sistem Informasi Geografis (SIG) adalah kumpulan yang terorganisir dari perangkat keras, perangkat lunak, data geografi dan personal yang dirancang secara efisien untuk memperoleh, menyimpan, memperbaharui, memanipulasi, menganalisis dan menyajikan semua bentuk informasi yang bereferensi geografis. Sebagian besar data yang ditangani dalam SIG merupakan data spasial yang memiliki informasi lokasi (spasial) dan informasi deskriptif (atribut). Data spasial ini dapat dibagi menjadi dua format yaitu data raster dan data vektor.

\section{METODE PENELITIAN}

\section{Penentuan Tingkat Kerentanan Terhadap Tsunami}

Analisa kerentanan yang dikaji dalam penelitian ini adalah kerentanan lingkungan, infrastruktur dan kerentanan sosial kependudukan. Variabel penyusun kerentanan lingkungan antara lain elevasi, kemiringan lereng (slope), morfologi pantai, landuse, jarak dari garis pantai, jarak dari sungai.

\section{HASIL DAN PEMBAHASAN}

Penentuan zona kerentanan dibutuhkan penyusunan peta kerentanan lingkungan dan kerentanan sosial kependudukan, ekonomi dan infrastruktur. Sumber data selain dari hasil survey juga berasal dari Peta RBI skala 1:25000 dan peta Rencana Tata Ruang dan Wilayah Kabupaten Lumajang 2008-2028.

\subsection{Pemetaan Kerentanan Lingkungan}

Peta kerentanan lingkungan pada gambar didapatkan dari overlay morfologi dan elevasi lereng dasar laut sekitar pantai, jarak dari sungai, penggunaaan lahan, ketinggian kelerengan dan keterlindungan daratan yang diperlihatkan pada gambar 3 . 


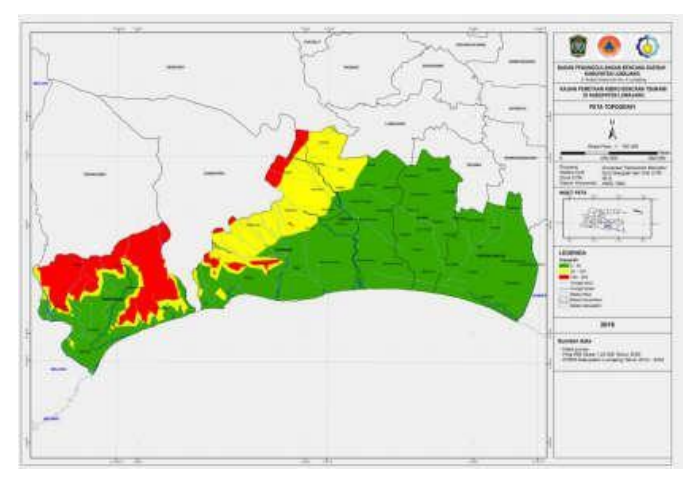

\section{Gambar 3. Peta Bentang Alam}

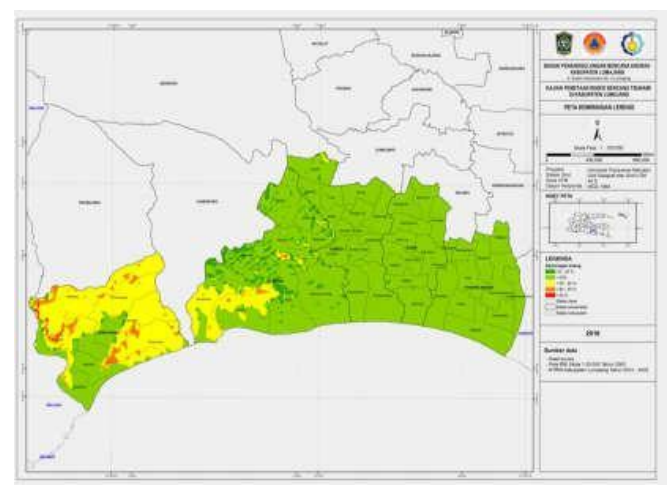

\section{Gambar 4. Peta Kemiringan Lereng}

Gambar 4 memperlihatkan kemiringan lereng yang cukup tinggi berada di kecamatan Tempursari dan Pasirian, sementara kecamatan lainnya dominan adalah dataran rendah.

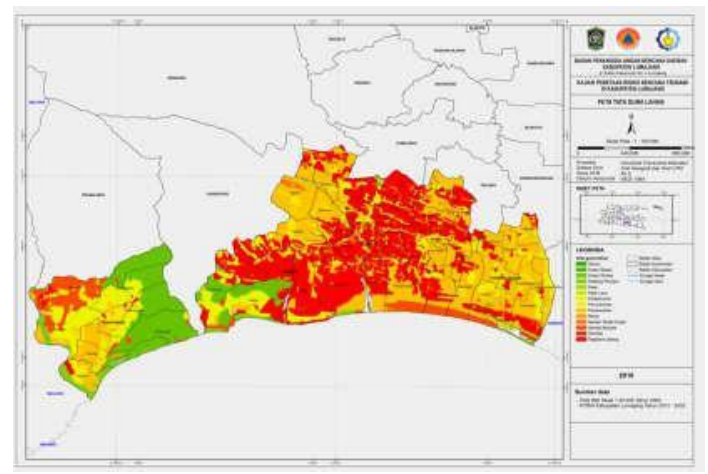

\section{Gambar 5. Peta Tata Guna Lahan}

Peta tata guna lahan memperlihatkan di Kecamatan Tempursari mempunyai danau dan hutan-hutan, sedangkan Kecamatan Pasirian, Tempeh dan Kunir terdapat sawah tadah hujan, tambak, semak semak dan ladang. Perkebunan dan sawah dominan terdapat di Timur Lumajang yaitu Kecamatan Yosowilangun.

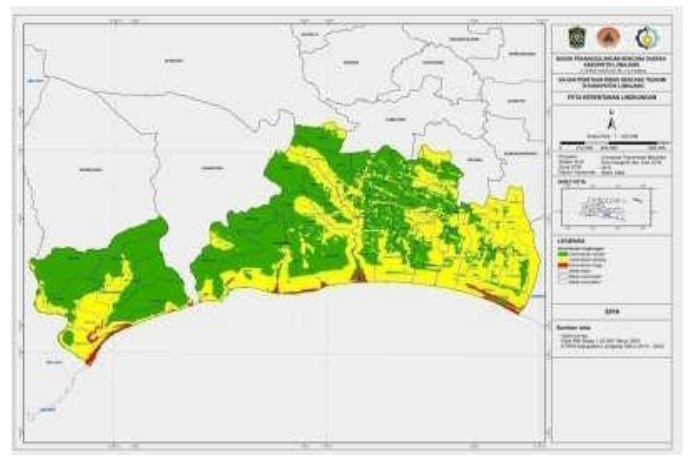

\section{Gambar 6. Peta Kerentanan Lingkungan}

\subsection{Pemetaan Kerentanan Sosial Kependudukan dan Ekonomi}

Hasil survei lapangan ini selain digunakan untuk crosscek data juga digunakan untuk update data pemukiman penduduk yang nantinya akan digunakan dalam tahapan pengolahan data. 


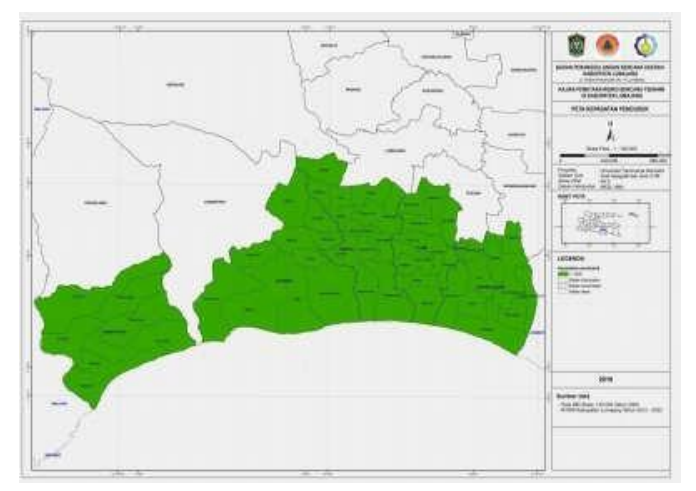

Gambar 7. Peta Kerentanan Kepadatan Penduduk

\subsection{Pemetaan Pemukiman dan Infrastruktur}

Peta kerentanan infrastruktur didapatkan dengan mengoverlay jarak jembatan, Jalur Lintas Selatan (JLS), dan Jaringan darat dengan jarak dari garis pantai yang menghasilkan 3 kelas. Peta Risiko yang tinggi jika jaraknya 0 - $200 \mathrm{~m}$ yaitu terdapat di Kecamatan Tempursari dan Yusowilangun. Kerentanan infrastruktur sedang berada pada Kecamatan Tempursari dan Yusowilangun, sedangkan kerentanan infrastruktur yang rendah berada pada Kecamatan Pasirian, Kecamatan Tempeh dan Kecamatan Kunir.

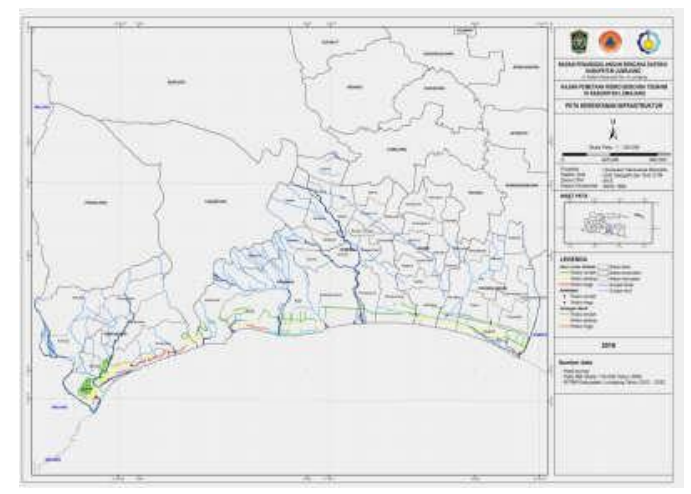

Gambar 8. Peta Kerentanan Infrastruktur

\section{KESIMPULAN}

1. Secara umum daerah yang berpotensi risiko terhadap kejadian tsunami berada pada wilayah pesisir Kabupaten Lumajang. Wilayah pesisir tersebut meliputi 5 Kecamatan di Kabupaten Lumajang yang berbatasan langsung dengan Pantai Selatan yaitu Kecamatan Yosowilangun, Kecamatan Kunir, Kecamatan Tempeh, Kecamatan Pasirian, dan Kecamatan Tempursari. Data-data parameter kerentanan memperlihatkan bahwa kecamatan-kecamatan di Kabupaten Lumajang yang berbatasan langsung dengan Pantai Selatan mempunyai topografi yang rendah dan kepadatan penduduk yang cukup tinggi.

2. Kerentanan Lingkungan yang tinggi hampir berada di sepanjang pesisir pantai daerah kajian Kabupaten Lumajang terutama di daerah pesisir pantai sebelah timur dan barat serta di sebagian Kecamatan Pasirian terutama di muaramuara sungai. Kerentanan sedang berada pada perbatasan Kecamatan Yosowilangun, Pasirian dan Tempursari. Kerentanan rendah terdapat di semua kecamatan sepanjang pantai.

3. Peta kerentanan infrastruktur didapatkan dengan mengoverlay jarak jembatan, Jalur Lintas Selatan (JLS), dan Jaringan darat dengan jarak dari garis pantai yang menghasilkan 3 kelas. Peta Risiko yang tinggi jika jaraknya $0-$ 200 m yaitu terdapat di Kecamatan Tempursari dan Yusowilangun. Kerentanan infrastruktur sedang berada pada Kecamatan Tempursari dan Yusowilangun, sedangkan kerentanan infrastruktur yang rendah berada pada Kecamatan Pasirian, Kecamatan Tempeh dan Kecamatan Kunir

\section{DAFTAR PUSTAKA}

Use the "Insert Citation" button to add citations to this document. 